\title{
Cross-Border Venture Capital Investments: What Is the Role of Public Policy?
}

\author{
Wendy A. Bradley ${ }^{1, * \mathbb{D}}$, Gilles Duruflé ${ }^{2}$, Thomas F. Hellmann ${ }^{3}$ and Karen E. Wilson ${ }^{4}$ \\ 1 Cox School of Business, Southern Methodist University, Dallas, TX 75275, USA \\ 2 QCC Tech Innovation Platform, Montreal, QC H2V 3J7, Canada \\ 3 Saïd Business School, University of Oxford, Oxford OX1 1HP, UK \\ 4 OECD and GV Partners, 1207 Geneva, Switzerland \\ * Correspondence: wabradley@smu.edu; Tel.: +1-214-768-2282
}

Received: 3 June 2019; Accepted: 26 June 2019; Published: 1 July 2019

\begin{abstract}
Background: Cross-border venture capital (VC) investments play an important role in the scaling up of high-growth companies. However, policymakers worry that foreign VC investments transfer the majority of economic activity to the investor country. On the one hand, start-ups welcome the foreign capital, expertise, and networks that accompany cross-border investments. On the other hand, policymakers are concerned that cross-border investments predominantly benefit foreign economies and fail to develop the local entrepreneurial ecosystem. This paper describes a framework for how policymakers can develop a set of policies toward cross-border VC investments. (2) Methods: The paper examines available data and trends about the role of cross-border investing, focusing on Europe, Israel, and Canada. Then, the paper explains the underlying economic challenges and develops a policy framework. (3) Results: The analysis shows that in addition to policies that aim to attract foreign investors, there are also important policies for the development of the domestic VC market. The analysis encompasses policies that are both financial and non-financial in nature. (4) Conclusions: A core insight for policymakers is to retain a balance of initiatives, attracting foreign investors while simultaneously making sure to strengthen the country's domestic VC industry and innovation ecosystem. The mix of policies will adjust as the domestic ecosystem matures.
\end{abstract}

Keywords: cross-border venture capital; internationalization; entrepreneurship policy; foreign venture capital firms; domestic entrepreneurs

\section{Introduction}

Traditionally, venture capital (VC henceforth) was a local industry. Geographic proximity of an investor firm to its portfolio company was considered crucial for identifying investment opportunities, monitoring, adding value, and achieving higher performance (Devigne et al. 2018; Mäkelä and Maula 2006; Sorenson and Stuart 2001). More recently, however, the VC industry has experienced international growth (Alhorr et al. 2008; Goodhart and Schoenmaker 2016; Meuleman and Wright 2009). Foreign investors, attracted by new opportunities and new markets, are investing outside their home country at growing rates. This has led to an increase in both the amount of foreign investment and the number of international exits by VC-backed companies. Questions emerge for policymakers whether these investments predominantly benefit foreign economies, or whether they also help to grow the local entrepreneurial ecosystems. The central policy question is: Should government policies facilitate cross-border venture capital investments; and, if so, how?

Policymakers lack a unified framework for analysing the issues associated with cross-border venture capital investments. Moreover, a lack of high-quality data and evidence about cross-border VC investments impedes making informed policy decisions. In some countries, such as Israel 
and Canada, policymakers have actively encouraged foreign investments, while others, including many European countries, implicitly discourage cross-border financing, or simply lack a clear set of policy guidelines. In this paper, we propose a coherent perspective to assess the advantages and disadvantages of cross-border VC investments. We outline the challenges faced by companies, investors, and policymakers, and present a framework for drafting appropriate policy responses.

This study builds on a review of the academic literature (see Devigne et al. 2018), as well as a summary of publicly available data, to develop a new framework analysing policy options for cross-border venture investing. Section 2 looks at the quantitative and qualitative data about the rise of cross-border investing. Section 3 develops a conceptual understanding of the economic challenges of cross-border investing. Section 4 develops the main policy analysis. It is followed by a brief conclusion.

\section{Trends in Cross-Border Venture Capital Investments}

This section outlines what we currently know about cross-border investments. Cross-border VC investment is defined as investments from investors located in a different country from the country where the portfolio company was founded. In our discussion, we mainly talk about $\mathrm{VC}$, but one can use a broad definition of this term. Although not our focus and thus excluded from our data, much of our analysis also pertains to other forms of early-stage financing, such as angel investing, corporate venturing, or crowdfunding. In general, cross-border VC investments make up a non-trivial part of the market, with an increasing trend over time. Relative to domestic VC investments, cross-border VC investments usually occur at later stages, are associated with larger rounds, larger exits, and with more foreign exits (Devigne et al. 2018).

Our data originates from three major sources. Section 2.1 looks at statistics from industry publications, Section 2.2 at the empirical academic literature, and Section 2.3 at some of the evidence available from looking at individual countries.

\subsection{Data from Industry Publications}

Data about cross-border VC investments remains limited. In this section, we provide an overview of the available evidence. A useful starting point are large deals (including unicorn deals that receive a lot of publicity). In Europe in 2017, there were 17 investment rounds over $€ 100$ million, compared to 13 rounds in 2016, including the notable $€ 500 \mathrm{M}$ investment in Spotify (Dealroom.co 2017). Most of these large rounds included foreign investors. In 2017, UK-based Improbable received €502M from Japanese investors, Portugal-based Farfetch €397M from Chinese investors, UK-based Deliveroo €397M from a round that included US investors, UK-based Truphone €337M from a syndicate that included Russian investors, and Germany-based SoundCloud $€ 170 \mathrm{M}$ from a syndicate that included UK and Singapore investors. ${ }^{1}$

Turning to more systematic data from Dealroom.co, we note that US investors contributed roughly $26 \%$ of funds to the European VC market in 2017, and this amount has increased over time. US VC investments in Europe increased from $\$ 11.3$ billion in 2016 to $\$ 12.0$ billion in 2017 (Figure 1).

1 To be more specific, Improbable received funding from Japanese SoftBank https://www.independent.co.uk/ news/business/news/japan-softbank-improbably-invest-500m-uk-tech-startup-a7732031.html, Farfetch from Chinese JD.com: https://techcrunch.com/2017/06/21/jd-com-invests-397m-into-luxury-marketplace-farfetch-as-part-of-a-newstrategic-partnership/, Deliveroo from a syndicate including Fidelity and T. Rowe Price: https://techcrunch.com/2017/09/ 24/deliveroo-raises-385m/, Truphone from a syndicate that included Russian investors: https://www.cnbc.com/2017/10/03/ truphone-raises-338-million-in-funding-backed-by-roman-abramovich.html, and Soundcloud from a syndicate of The Raine Group and Singapore-based Temasek: https://www.musicbusinessworldwide.com/soundcloud-posted-a-82m-loss-in2016-but-took-on-170m-in-investment-last-year/. 


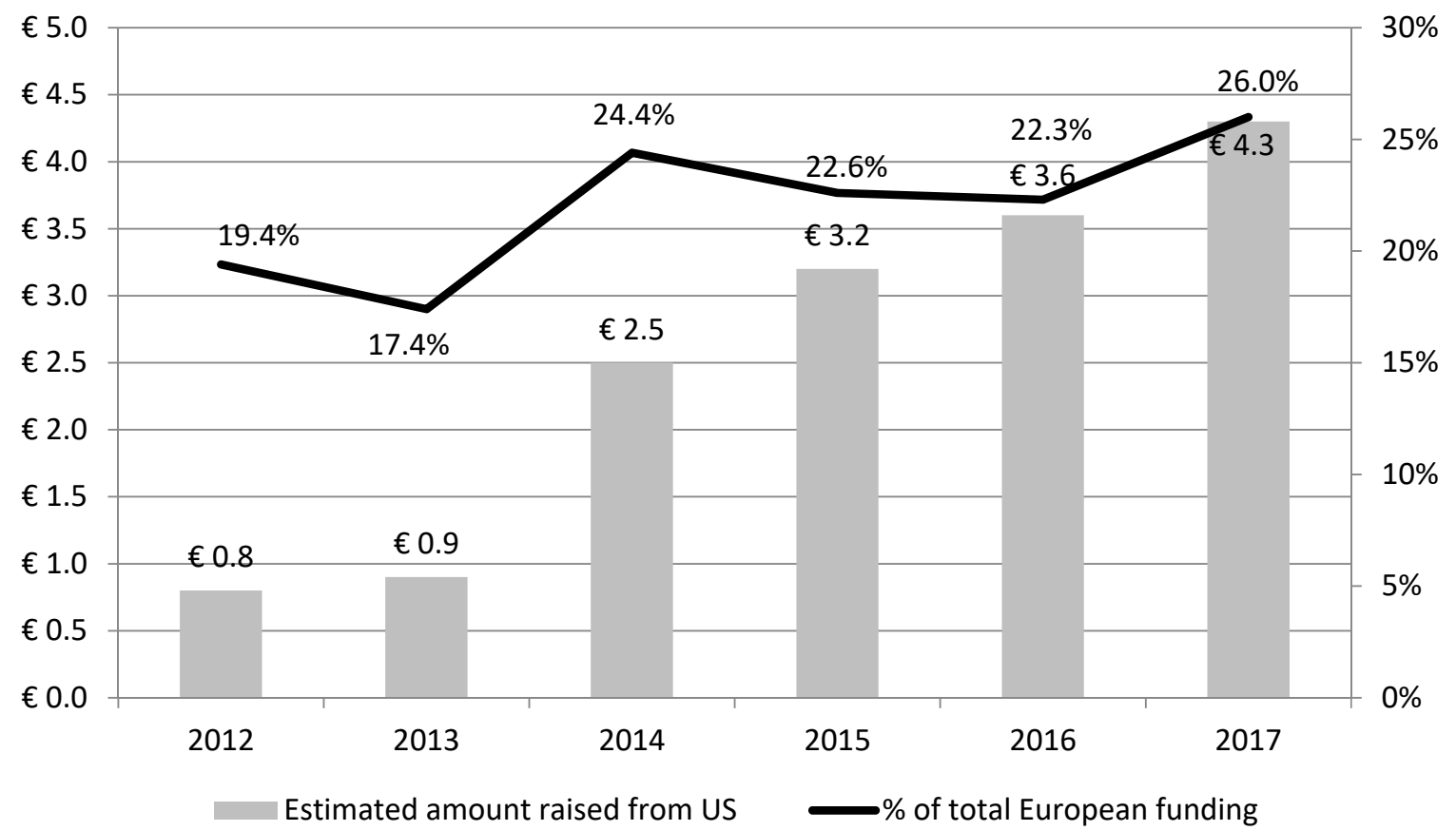

Figure 1. US investment in Europe by amount invested (€B) (Dealroom.co 2018).

In 2017, more than 450 investment rounds in European companies involved US VCs (Table 1). The number of deals with US participation has increased more than the amount invested by US investors over time, which implies that the average size of these US participations has decreased (Tables 1 and 2). Tables 1 and 2 provide a more detailed breakdown of the data for US, Europe, and worldwide VC investment in European companies.

Table 2 shows that most of the VC amount invested in European companies comes from European investors (56\%, including domestic investors). The US and Canada are the next largest investors by dollar invested in Europe (26\%) and then Asia (13\%). The UK invests more capital outside its own country than any other European country (Dealroom.co 2017). In 2017, investment in the UK grew by $87 \%$ to $€ 7.1$ billion, more than Germany, France, and Sweden combined (Dealroom.co 2018). About 50\% of investment into the UK comes from foreign investors (31\% from US investors; $22 \%$ other foreign). Within the UK, foreign investors often fill the scale-up financing gap. In Series E rounds, for example, only $25 \%$ of investors in the UK come from the UK (Hellmann et al. 2016).

The countries in Europe that rely most on foreign VCs are Austria, Ireland, Sweden, and Spain, accounting for over 70\% of their VC investments. Figure 2 graphically represents the composition of $\mathrm{VC}$ invested by individual countries. 
Table 1. (a) Number of VC rounds by location of investors and investees (2017) (Dealroom.co 2018). Most European investment rounds occur domestically. Of 817 rounds into European companies involving UK investors, 588 rounds were for UK-based companies. US investors are predominantly interested in the UK and Germany. (b) Of 828 total rounds in the UK in 2017, 157 rounds involved a North American (US and Canada) investor. This means roughly $20 \%$ of UK investment rounds have a US or Canadian investor. Of 828 total rounds in the UK in 2017, 657 rounds involved European investors. This means $79 \%$ of all UK investment rounds in 2017 had a European investor.

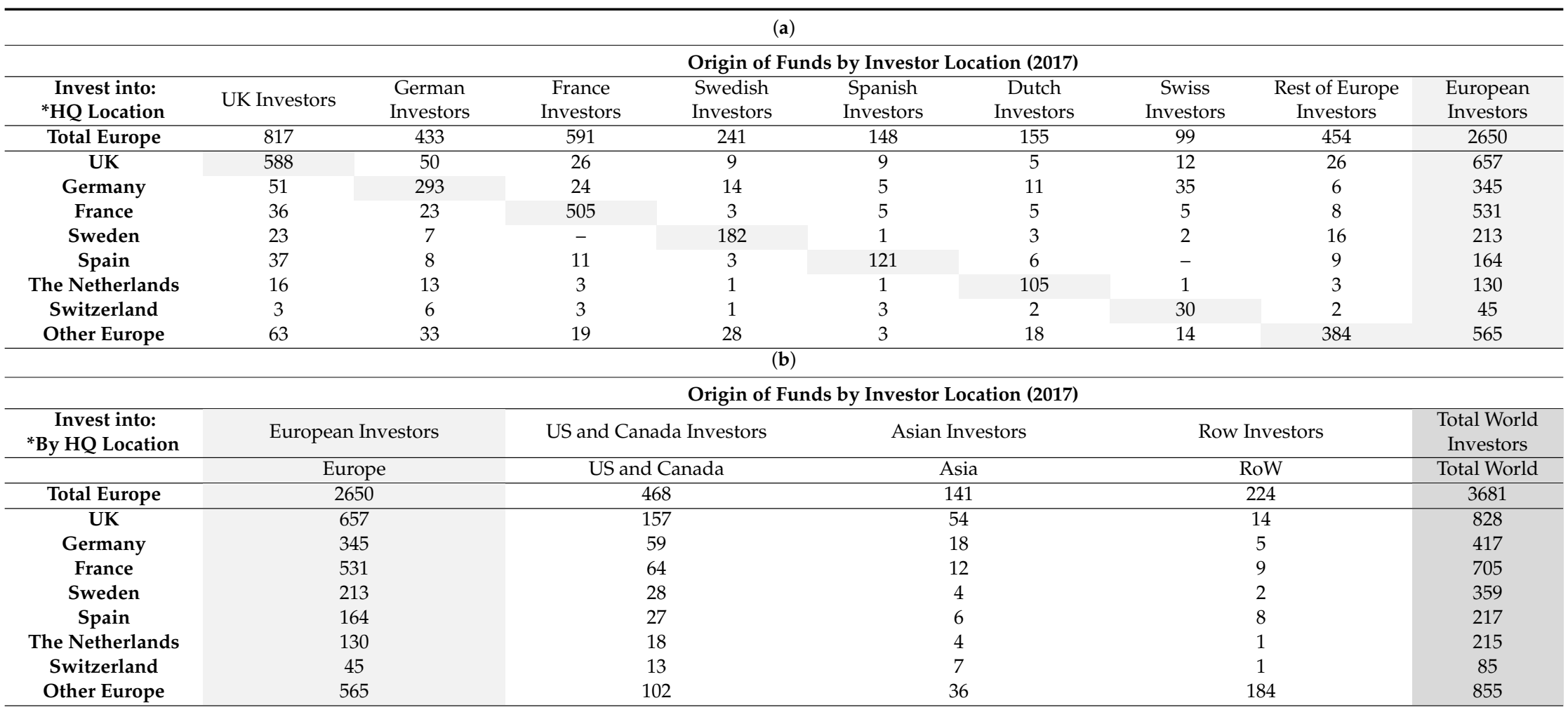


Table 2. (a) Percentage of VC amount contributed by investor and investee location (2017) (Dealroom.co 2018). Fifty-six percent of the total amount received by European companies comes from European VC funds, or \$10.9B, into European companies. UK investors contribute $22 \%$ of total VC amount received by European companies. The UK invests more capital outside its own country than any other country in Europe. Together, the UK and US are responsible for almost half of all capital invested into Europe at 22\% and 26\%, respectively (Dealroom.co 2018). (b) Together, the UK and US are responsible for almost half of all capital invested into Europe at $22 \%$ and $26 \%$, respectively (Dealroom.co 2018).

\begin{tabular}{|c|c|c|c|c|c|c|c|c|c|}
\hline \multicolumn{10}{|c|}{ (a) } \\
\hline & \multicolumn{9}{|c|}{ Origin of Funds by Investor Location (2017) } \\
\hline $\begin{array}{c}\text { Invest into: } \\
{ }^{*} \text { By HQ Location }\end{array}$ & UK Investors & $\begin{array}{c}\text { German } \\
\text { Investors }\end{array}$ & $\begin{array}{c}\text { France } \\
\text { Investors }\end{array}$ & $\begin{array}{l}\text { Swedish } \\
\text { Investors }\end{array}$ & $\begin{array}{l}\text { Spanish } \\
\text { Investors }\end{array}$ & $\begin{array}{c}\text { Dutch } \\
\text { Investors }\end{array}$ & $\begin{array}{c}\text { Swiss } \\
\text { Investors }\end{array}$ & $\begin{array}{l}\text { Rest of Europe } \\
\text { Investors }\end{array}$ & $\begin{array}{l}\text { European } \\
\text { Investors }\end{array}$ \\
\hline Europe & $22 \%$ & $9 \%$ & $10 \%$ & $4 \%$ & $2 \%$ & $3 \%$ & $2 \%$ & $4 \%$ & $56 \%$ \\
\hline UK & $36 \%$ & $4 \%$ & $3 \%$ & $1 \%$ & $1 \%$ & $0 \%$ & $2 \%$ & $0 \%$ & $48 \%$ \\
\hline Germany & $13 \%$ & $23 \%$ & $6 \%$ & $2 \%$ & $1 \%$ & $2 \%$ & $5 \%$ & $0 \%$ & $51 \%$ \\
\hline France & $13 \%$ & $6 \%$ & $51 \%$ & $0 \%$ & $0 \%$ & $4 \%$ & $2 \%$ & $0 \%$ & $77 \%$ \\
\hline Sweden & $12 \%$ & $9 \%$ & - & $40 \%$ & $0 \%$ & $2 \%$ & $0 \%$ & $5 \%$ & $68 \%$ \\
\hline Spain & $15 \%$ & $4 \%$ & $4 \%$ & $6 \%$ & $21 \%$ & $3 \%$ & - & $0 \%$ & $53 \%$ \\
\hline The Netherlands & $11 \%$ & $10 \%$ & $5 \%$ & $0 \%$ & $4 \%$ & $48 \%$ & $0 \%$ & - & $78 \%$ \\
\hline Switzerland & $7 \%$ & $7 \%$ & $9 \%$ & $3 \%$ & $1 \%$ & $2 \%$ & $20 \%$ & - & $48 \%$ \\
\hline Other Europe & $12 \%$ & $7 \%$ & $4 \%$ & $4 \%$ & $0 \%$ & $4 \%$ & $2 \%$ & $27 \%$ & $60 \%$ \\
\hline \multicolumn{10}{|c|}{$(\mathbf{b})$} \\
\hline & \multicolumn{9}{|c|}{ Origin of Funds by Investor Location (2017) } \\
\hline $\begin{array}{c}\text { Invest into: } \\
\text { *By HQ Location }\end{array}$ & \multicolumn{2}{|c|}{ European Investors } & \multicolumn{2}{|c|}{ US and Canada Investors } & \multicolumn{2}{|c|}{ Asian Investors } & \multicolumn{2}{|c|}{ RoW Investors } & $\begin{array}{c}\text { Total World } \\
\text { Investors }\end{array}$ \\
\hline Total Europe & \multicolumn{2}{|c|}{$56 \%$} & \multicolumn{2}{|c|}{$26 \%$} & \multicolumn{2}{|c|}{$13 \%$} & \multicolumn{2}{|c|}{$5 \%$} & $\$ 19.4 \mathrm{~B}$ \\
\hline UK & \multirow{2}{*}{\multicolumn{2}{|c|}{$\begin{array}{l}48 \% \\
51 \%\end{array}$}} & \multicolumn{2}{|c|}{$30 \%$} & \multicolumn{2}{|c|}{$20 \%$} & \multicolumn{2}{|c|}{$2 \%$} & $\$ 7.4 \mathrm{~B}$ \\
\hline Germany & \multirow{2}{*}{\multicolumn{2}{|c|}{$\begin{array}{l}51 \% \\
77 \%\end{array}$}} & \multirow{2}{*}{\multicolumn{2}{|c|}{$24 \%$}} & \multirow{2}{*}{\multicolumn{2}{|c|}{$11 \%$}} & \multicolumn{2}{|c|}{$14 \%$} & $\$ 3.1 \mathrm{~B}$ \\
\hline France & & & \multirow{2}{*}{\multicolumn{2}{|c|}{$27 \%$}} & \multirow{2}{*}{\multicolumn{2}{|c|}{$4 \%$}} & & $\%$ & $\$ 2.6 \mathrm{~B}$ \\
\hline Sweden & \multicolumn{2}{|c|}{$68 \%$} & & & & & & $\%$ & $\$ 1.3 \mathrm{~B}$ \\
\hline Spain & & & & & & & & $\%$ & $\$ 0.9 \mathrm{~B}$ \\
\hline The Netherlands & & & & & & & & $\%$ & $\$ 0.6 \mathrm{~B}$ \\
\hline Switzerland & & & & & & & & - & $\$ 0.3 \mathrm{~B}$ \\
\hline Other Europe & & & & & & & & $\%$ & $\$ 3.1 \mathrm{~B}$ \\
\hline
\end{tabular}




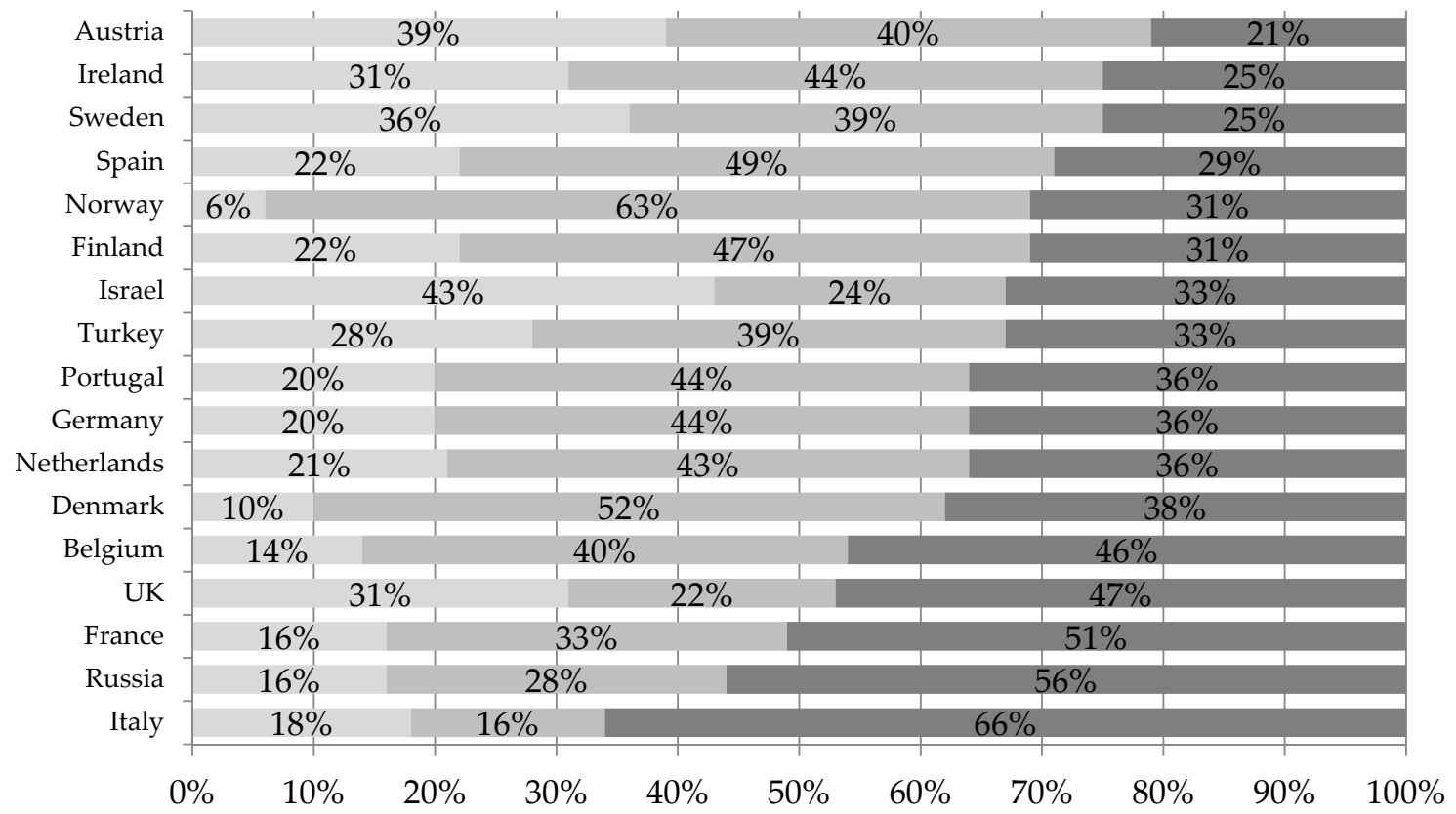

U.S. $\quad$ Other foreign $\quad$ Domestic

Figure 2. Country origins of investment amounts across European countries (2016) (Dealroom.co 2017). The figure assumes rounds with multiple investors are equally allocated and is based on investor HQ location. Other foreign refers mostly to other European.

Like Europe, Canada's VC market is growing. In 2017, total annual VC funding in Canada reached $\$ 2.7$ billion, distributed across 333 deals; total funding increased $7 \%$; deal activity decreased $12 \%$ but the average deal size increased by 31\%, from $\$ 8.3$ to $\$ 10.9$ million in 2017 (PwC/CB Insights Canada 2018). There were several mega rounds and VC-backed unicorns funded by foreign investors: Montreal-based Element AI (\$135M from US and international investors), Waterloo-based eSentire (from US and other global investors), Toronto-based PointClickCare (\$85M from US investors), and Ottawa-based Assent Compliance (\$32 million from US investors) (PwC/CB Insights Canada 2018). Foreign VC investments in Canada predominantly come from the US, representing $26 \%$ of all deals and almost 50\% of the total VC amount invested in Canadian companies (PitchBook 2015, 2017). From 2012 to 2015, the total amount invested in deals with US participation by dollar amount steadily increased. Most US investments in Canada occur at later stages (BDC Capital 2017). Canada thus falls in line with the global trend of foreign investors focusing on larger, later stage deals.

Israel also relies heavily on US VC investment, and these investments are increasing. Israeli tech companies raised $\$ 4.43$ billion in 2015, which was roughly 30\% more than in 2014 . Figure 2 shows that in 2016, $43 \%$ of funding came from US investors. Moreover, VC deals with US participation represent $85 \%$ of the total amount invested in Israeli VC deals in 2015 (Zemer 2018). US investors invest more VC funds per inhabitant in Israel than they do at home. Whereas US VC firms invested $\$ 250$ per capita domestically in 2017, US VC firms invested $\$ 368$ per capita in Israel (Dealroom.co 2017). By comparison, US VC investments per inhabitant in Sweden and the UK were $\$ 136$ and $\$ 120$, respectively. These two countries were next highest in levels of US investment per capita abroad.

Clearly, the US is a major player in international VC investments. However, in Europe, other foreign investors are contributing rapidly, such as the UK, Germany, and France (Dealroom.co 2018). Moreover, there is a global trend that Asian investors, especially Chinese are increasingly investing not only in the US, but also in Europe, Israel, and Canada (Dealroom.co 2017; Huang 2018; Lee 2018; Weinland 2018). 


\subsection{Empirical Evidence from Academic Papers}

Most of the academic literature on cross-border VC investments address: (1) which countries invest across borders and where; (2) the factors that influence the decision of VC firms to invest across borders; (3) and the effects on company performance of cross-border investments.

The academic literature notes that several country-specific characteristics are associated with an increase in the amount of foreign VC investment between two countries, including geographical distance, common language, and colonial ties (Aizenman and Kendall 2008). Firms enter foreign markets (1) based on the magnitude of trade ties, (2) based on the presence of transnational communities (i.e., links through migration), and (3) with high numbers of domestic collaborators who already operate in the new market (previous investment collaborations) (Guler and Guillén 2010). The size of the private equity industries in two countries increases the number of cross-border transactions between those two countries (Tykvová and Schertler 2008, 2011). The work of Gu and Lu (2010) and Sun and Liang (2014) establish the linkages between inward and outward cross-border venture investments. Moreover, trust among nations also affects international investment decisions (Bottazzi et al. 2016).

Intellectual property protection and legal institutions are also drivers of cross-border investments at the country level. According to work by Groh, Liechtenstein, and Canela (2008), the level of protection of property rights in a country is the dominant concern for making cross-border investment decisions (Groh et al. 2008). Another study shows that countries with better legal protection have more active investors that exercise more corporate governance (Bottazzi et al. 2009). Related to this, the work of Chen and Sun (2019) explains how financial contracts and governance practices from cross-border investments influence the development the domestic institutional legitimation and legalization of these practices. Furthermore, the work of Sun, Chen, Sunny, and Chen (2018) explains that the broader process of venture capital can foster the innovation ecosystem (Sun et al. 2018).

There are many firm-specific drivers for cross-border investments, both at the level of VC firms and portfolio companies. Higher quality of management and skills of local entrepreneurs are associated with an increase in cross-border investing (Groh and Liechtenstein 2011; Guler and Guillén 2010). The international experience of the management team is also strongly associated with foreign investments (Hursti and Maula 2008). Research shows that local VC firms typically invest first, followed by foreign VC firms in later rounds (Mäkelä and Maula 2008). Foreign VC firms located in a venture's target market of internationalization can be valuable for the venture by legitimizing the unknown new venture in that market (Mäkelä and Maula 2005). Certain third-party firms also affect the propensity of cross-border VC investing. The direct and indirect network ties of financial intermediaries are associated with cross-border investments (Jäs̈skeläinen and Maula 2014).

For VC firms, the decision to invest abroad depends on the returns from investment. Some studies find that, after controlling for portfolio company quality and VC firm reputation, international VC firms are less likely than purely domestic VC firms to have successful exits (Humphery-Jenner and Suchard 2013). The mechanism for why such evidence exists is linked to the liabilities of foreignness research, which shows that information asymmetries and more limited resource transfers restrict the success of cross-border investments (Devigne et al. 2016). In addition, compared to domestic investors, foreign investors are associated with lower escalation of commitment and higher willingness to terminate ventures (Devigne et al. 2016).

By contrast, several other studies find evidence that foreign investors are associated with more exits, such as an increased likelihood for initial public offerings (IPOs) and mergers and acquisitions, faster exits, and higher valuations (Bertoni and Groh 2014; Chahine and Saade 2011). The relationship between foreign investors and exit performance therefore remains inconclusive. There is also a problem with establishing clear causal links, and the role of selection effects. The work by Bottazzi et al. (2009), for example, shows how performance differentials of foreign investments can be largely explained by the selection of deals.

A few studies look at measures of company performance other than exit. Devigne et al. (2013) show that foreign VC firms are associated with lower short run sales growth, but higher medium-term 
sales growth (Devigne et al. 2013). Companies backed by a syndicate with both domestic and foreign VC investors outperform all other VC combinations in terms of an increase of sales, total assets, and employment (Chemmanur et al. 2016). Overall, we note that while the academic literature provides useful guidance on the drivers of cross-border investing, the question of relative investment performance remains largely unresolved.

\subsection{Country Experiences}

The role of foreign investors differs by country. In this section, we consider four country case studies that are particularly revealing: Israel, Canada, the UK, and France.

\subsubsection{Israel}

For decades, the military played a unique role in developing the VC market in Israel. The first limited partnership VC fund in Israel, Athena Venture Partners, was founded in 1985 by the former Chief of Staff of the Israel Air Force and two VC experts from the US. At the time, Israel already hosted several international R\&D Centres, including major technology firms like Intel. To cement its position as a leading innovation centre, the Israeli government passed regulations in the 1980s to encourage further relocation of R\&D centres. This, along with tax cuts in the 1980s and the ICT technology boom of the 1990s, led to a local entrepreneur boom in Israel. In 1987, the cancellation of the Lavi fighter-plane mega-project also inundated the domestic labour market with an influx of engineers and ex-military employees (Isenberg 2011). As the local entrepreneurs could not find the financial resources at home, the government set up a programme to jump-start its local VC industry in 1993, called YOZMA I. A unique aspect of this programme was that it offered attractive tax incentives to foreign venture-capital investments in Israel. It also promised to double any investment with funds from the government. YOZMA I created ten funds that were led by private sponsors, each capitalized with $\$ 20$ million. A few years later, along with co-investment from prominent American, European, and Israeli investors, the Israeli government created YOZMA II and YOZMA III. The YOZMA programmes created professionally managed funds that contributed not only venture capital but also recruited senior managers, designed business strategies, raised additional capital rounds, and attracted strategic and financial investors to its portfolio companies. YOZMA funds managed more than $\$ 220$ million and made direct investments in approximately 50 portfolio companies. From 1991 to 2000, the number of companies launched using Israeli venture funds rose from 100 to 800 . Israel's information-technology revenues rose from $\$ 1.6$ billion to $\$ 12.5$ billion. By 1999, Israel ranked second only to the United States in invested private-equity capital as a share of GDP (Gilder 2009). By 2018, Israel ranked first.

Today, Israel remains a hub for entrepreneurial ventures in all sectors. It attracts $15 \%$ of the world's VC investments in cyber-security, as well as other significant investments in agricultural and water technology, artificial intelligence, health services, and financial technology (The Economist 2017). In 2017, Israel had one start-up for every 1400 people. These companies, many of which are founded by serial Israeli entrepreneurs, also raise large international investment rounds, including Via $(\$ 250 \mathrm{~m})$, Lemonade $(\$ 120 \mathrm{~m})$, Cybereason $(\$ 100 \mathrm{~m})$, Vayyar $(\$ 45 \mathrm{~m})$, Airobotics $(\$ 32.5 \mathrm{~m})$, and Monday.com $(\$ 25 \mathrm{~m})$.

Israel is widely considered the poster child of success for building an innovation ecosystem. This success was clearly aided by policies that attracted foreign investments (Razin 2018). It is nevertheless important to note that with 8.5 million people, Israeli is nearly 40 times smaller in population than the US, and almost 90 times smaller in population than Europe. Because of its small size, Israeli has close interpersonal and inter-business networks to rely on. The interconnectedness of Israeli networks in the ecosystem has been attributed to the success of entrepreneurship in Israel. For example, as far back as 1987, MIT Professor Ed Roberts founded a mentoring network of 50 Boston-based Jewish technology entrepreneurs called the Technion Entrepreneurial Associates (Isenberg 2011).

However, despite its early policy actions to attract foreign investors, there are also downsides to being a "Startup Nation". Few of these ventures scale up within Israel. Instead, most Israeli 
start-ups are acquired by foreign companies. Several of these foreign exits involved multi-billion dollars acquisitions. Waze, a community-based traffic and navigation app developed near Tel Aviv in 2008, was sold to Google for $\$ 1.3$ billion. Mobileye, vehicular anti-collision software developed in Jerusalem in 1999, was sold to Intel for $\$ 15.3$ billion (Bordo 2018). As Israeli founders and employees move abroad, this adversely affects local employment and economic growth (Duruflé 2018).

\subsubsection{Canada}

The venture capital industry in Canada started in the early 1990s and grew rapidly during the decade with a strong support of governments (direct funds and tax credit to retail funds ${ }^{2}$ ), financial institutions (direct investment and some indirect investment) and pension funds (direct and indirect investment). There were relatively few private independent funds.

This rapid growth of the VC industry supported the emergence of first generations of tech entrepreneurs and start-ups. However, after the crash of the tech bubble, returns proved to be very negative for all classes of investors: government and government supported funds as well as private sector. ${ }^{3}$ It appeared that overall the industry had not started with the right profile of investors, nor a set of best practices to replicate the success of the US industry (Durufle et al. 2018).

This led to a reset: most financial institutions and pension funds left the asset class; LSVCCs were phased out outside Quebec and in Quebec they left early stage direct VC investment and turned to indirect investment; provincial governments shifted from direct investment to indirect investment; pension funds that remained in the asset class because they had economic development objectives did the same; the federal government, through BDC, maintained a direct investment arm but in parallel increased its indirect investment capacities and later supported the set up of fund-of-funds dedicated to invest in VC funds through the Venture Capital Action Plan (VCAP) and the Venture Capital Catalyst Initiative (VCCI).

All these initiatives were based on the consensus that the objective was to support the development of a strong and self-sustainable Canadian private sector VC industry. This required nurturing and selecting the right profile of managers, adopting industry best practices that had been largely developed in the US, and attract leading US funds for their capital, networks and expertise.

During the first phase of development (1990-2005), the dominant position was that government support should be predominantly, if not strictly, directed to Canadian companies and Canadian VC funds. After the reset, this position evolved: in order to benefit from the foreign (mostly US) capital, expertise and networks, government policies should not limit cross-border investing, nor should they limit Canadian VC funds to co-invest with leading US funds, neither in Canada nor in the US.

To this end, important fiscal hurdles that limited investment by foreign funds in Canada, (especially Section 116 of the Income Tax Act) were removed. Moreover, government supported fund-of-funds programmes were designed not only to fund local managers but also to attract foreign investors. Conditions were that foreign recipients would open a significant office in Canada and that enough funds would be invested in Canada. For this, a portfolio approach was taken that required some multiple (less that 2) of the government allocation to be invested in Canadian companies.

The impact of these measures was far from immediate but over a twelve-year period, significant improvements have been registered. Overall, VC investment in Canada has surged. Foreign investment now represents more than $50 \%$ of total VC investment in Canada. VC inflows to Canada are larger that outflows. Top international funds and fund-of-funds (mostly from the US) have opened offices in Canada. A group of leading Canadian VC managers is now emerging, the size of their funds is growing, and they are becoming increasingly recognized in the US and beyond. Importantly, returns

2 These funds supported by tax credits to retail investors were called Labor Sponsored Venture Capital Corporations (LSVCC). 3 The pooled average for the private independent funds was not any better than for government funds and LSVCCs. However, the dispersion of returns was much larger for private sector funds. There was a first quartile of private sector funds that had acceptable returns, but most private sector funds had poor to very poor returns (see Duruflé 2018). 
in the Canadian VC industry have improved, and leading Canadian funds are now able to raise most of their funding from private sector investors.

As in Israel, there is a growing concern that very few Canadian VC-backed companies scale up in Canada and that the large role played by foreign investors may increase the probability of promising companies moving South of the border or being acquired (too early) by foreign companies.

The thinking presently is that the best ways to address these issues are (i) to strengthen the Canadian VC industry so that Canadian VC funds can keep a lead position in the investment syndicate and influence the outcome for the company and (ii) to strengthen the ecosystem so that companies find the right environment to grow in Canada.

Regarding the first point, government supported fund and fund-of-funds programmes have now an explicit priority to fund larger, stronger and more experienced Canadian VC funds. Several of them have set up co-investment programmes to back underlying Canadian funds investing in large rounds of promising Canadian companies. Supporting scale-up companies is one of the main objectives of the latest VCCI programme at the federal level. Regarding the second point, training programmes for CEOs of scale-up companies have been set up and initiatives such as the Innovation Supercluster Initiative are being deployed to link emerging companies with larger corporations (Duruflé 2018).

\subsubsection{The United Kingdom}

In Europe, the UK leads in cross-border VC investments. The UK has long been a hub for European VC investors and start-ups. Contributing to this history is the fact that the UK attracts English-speaking investors from the US. London is a European financial centre, and the UK government has longstanding programmes for developing start-ups and its domestic base. Several of these programmes are now run by the British Business Bank (BBB), such as the Enterprise Capital fund (investments of $£ 330 \mathrm{M}$ ), the VC Catalyst fund (investments of $£ 145 \mathrm{M}$ ), and the Angel Co-investment fund (investments of $£ 145 \mathrm{M}$ ).

The BBB does not have direct policies targeting foreign VC investors, although several of its programmes are accessible to foreign investors investing in UK companies. At the same time, UK Trade and Investment, a government department, is actively trying to attract foreign investors, including for early stage venture deals.

The BBB also aims to increase the transparency of its domestic VC market by improving the quality and accessibility of investment information about the UK. Closely related, the British Private Equity and Venture Capital Association recently presented research on European venture returns, which suggests that Europe is outperforming the US in terms of internal rates of return (IRRs), strong unicorn exits, and lower entry valuations. ${ }^{4}$ After many years of underperformance, at least parts of the European venture capital market now appear to generate sustainable returns. Efforts to provide transparent returns data, and to disseminate their message, are likely to help Europe attract more foreign VC investment.

\subsubsection{France}

Public institutions play a major role in developing France's ecosystem for VC investors. In recent years, Bpifrance, the French development bank, has focused on an integrated investment strategy. It manages an entire family of funds and fund-of-funds to invest in young French companies. It keeps a minority position in the invested funds, sharing the same rights as other investors ("pari passu"). The goal is to attract private investors to these VC funds to share the risks and help to grow the ecosystem.

Since the 1990s, Bpifrance has launched more than 10 fund-of-funds. These funds are predominantly dedicated to VC funds in later stage ventures and balanced stages, although two programmes were exclusively dedicated to seed funds. Bpifrance has invested an additional $€ 2$ billion in over $130 \mathrm{VC}$ funds, including 50 seed funds and 80 later stage and balanced funds, jointly with 
other private investors. Bpifrance also manages direct funds to cover company development stages for which the supply of private funds is lacking (Acevedo et al. 2016). Thus, government agencies are the biggest investors in French VC funds today.

In 2017, France overtook the UK in the amount of fundraising. French VC funds raised $€ 2.7$ billion ( $£ 2.4$ billion), compared with $€ 2.3$ billion in the UK (Dealroom.co 2017). This is the first time France has raised more venture capital money than the UK. As a country's VC market develops, this has implications for the level and direction of cross-border investment activity and the role of policy in mitigating the risks and amplifying the advantages. However, it appears that on average the performance of French VC funds is still inferior to the performance of UK and US funds (Acevedo et al. 2016; Autorité des Marchés Financiers 2014).

Because France has a smaller but growing VC ecosystem, French policymakers are working to attract non-French funds directly by investing in international partners that are already working with French funds and by ensuring these international partners remain paired with local funds. In this way, the international partners can learn more about the local entrepreneurial ecosystem in France. This also gives Bpifrance confidence that its own investment mandates are fulfilled. Bpifrance already has an agreement with KfW (Germany) to fulfil this objective of building pan-European funds (Duruflé 2018).

In addition, France is also working to create a French-China-US GP. One team will be in China, one in Silicon Valley, and one in France. This initiative is fully cross-border integrated, with a goal of sourcing value-adding companies across those geographies. The main purpose is to attract the best teams in the market, create value by developing start-ups, and providing an international outlook from the outset.

\section{Framework for Understanding Cross-Border Venture Capital Investments}

How can companies, investors, and policymakers make sense of the challenges associated with cross-border VC investments? In this paper, we develop a framework for policymakers that conceptualizes the advantages and disadvantages of cross-border investments. The framework is designed to help policymakers create interventions that are the appropriate for their ecosystem and their policy goals.

\subsection{Advantages and Disadvantages of Cross-Border VC Investments}

Policymakers can consider cross-border investments with respect to two levels of analysis: transaction-level and ecosystem-level. At the transaction level, the question we ask is: "How do entrepreneurs and VC investors decide whether and when to engage in cross border investing?" At the ecosystem level we ask: "What is the effect of cross border venture investments on the local ecosystem?"

With this, we now examine the advantages and disadvantages for two different stakeholders: investors, which are the VC firms, and entrepreneurs, who operate VC-backed companies. Table 3 summarizes the main advantages and disadvantages of cross-border investments. It distinguishes between a transaction level and an ecosystem level. It also distinguishes between (i) the domestic companies and their ecosystem and (ii) the foreign investors and their ecosystem.

The direct effects of cross-border investment occur at the transaction level. Foreign investors are looking for attractive investment opportunities. Local companies may receive lower valuations, especially compared to Silicon Valley. In addition, foreign VCs might identify local companies with potential exit options in their home market where the exit markets might be more liquid than in the local market. For a foreign VC fund, investing in local companies can also help the firm to diversify its investment portfolio, and possibly to differentiate itself from other purely domestic competitors. Moreover, cross-border investments allow VC firms to pursue a "global specialist strategy". They focus on a limited number of sectors but use the cross-border element to achieve the necessary scale. At the same time, VC firms investing abroad face a host of business and regulatory challenges. Ownership restrictions or high tax burdens can hinder a foreign VC firm's ability to invest cross-border. Within 
Europe, for example, there are 27 different national investment regulations. A VC firm that wants to invest in several European countries will face considerable difficulties acquiring all the required country-specific knowledge regarding investments and taxes. In addition, making foreign investment requires constant learning, and a certain level of commitment. There is a fixed cost element to this, making it particularly difficult for smaller VC firms.

Table 3. This table compares the advantages and disadvantages of cross-border investing.

\begin{tabular}{|c|c|c|c|}
\hline Per & ective & Advantages & Disadvantages \\
\hline \multirow{2}{*}{$\begin{array}{l}\text { Domestic } \\
\text { Companies }\end{array}$} & Transaction level & $\begin{array}{ll}- & \text { Funding } \\
\text { - } & \text { Networks } \\
\text { - } & \text { Expertise }\end{array}$ & $\begin{array}{ll}\text { - } & \text { Distance } \\
\text { - } & \text { Investor lack } \\
& \text { commitment and } \\
& \text { local understanding }\end{array}$ \\
\hline & Ecosystem level & $\begin{array}{ll}\text { - } & \text { Grow ecosystem } \\
\text { - } & \text { Role models } \\
\text { - } & \text { Global connectivity }\end{array}$ & $\begin{array}{ll}\text { - } & \text { Crowding out } \\
& \text { local investors } \\
\text { - } & \text { Company relocation } \\
\text { - } & \text { Brain drain }\end{array}$ \\
\hline \multirow{2}{*}{ Foreign Investors } & Transaction level & $\begin{array}{l}\text { Investment opportunities } \\
\text { - Networks }\end{array}$ & $\begin{array}{ll}\text { - } & \text { Barriers and costs } \\
\text { - } & \text { Requires learning } \\
\text { and focus }\end{array}$ \\
\hline & Ecosystem level & $\begin{array}{l}\text { Inflow of foreign } \\
\text { entrepreneurs enrich } \\
\text { ecosystem diversity }\end{array}$ & $\begin{array}{l}\text { Drain on } \\
\text { financial resources }\end{array}$ \\
\hline
\end{tabular}

From the company perspective, accepting foreign venture investors holds the promise of access to capital, networks, and expertise. Companies in underdeveloped VC markets are particularly keen to access such resources. Companies seeking a specific sector expertise or network, including strategic partners or customers, can benefit from foreign investors that are more specialized and have larger market reach. A key role of a VC firm is to provide its portfolio companies with expertise and networks to prepare for exit, either going IPO or getting acquired. Foreign investors may provide access to foreign corporations, which may generate better exit opportunities for the company. At the same time, there can be real disadvantages of accepting funding from foreign investors. Being located far away, foreign investors may not stay in close communication. If they do, the foreign investors may lack proper understanding of the local ecosystem and provide the wrong type of advice. There is also a question about the level of commitment to the company and the country, and whether foreign investors give up earlier in downtimes (Devigne et al. 2016).

At the ecosystem level, cross-border investment can have several indirect effects. An ecosystem comprises other entrepreneurs, investors, and all supporting entities that surround the initial cross-border investment. Ecosystems tend to be highly interactive and networked, driven by information and thick market effects (Pierrakis and Saridakis 2019).

From the perspective of the investor country, an investment abroad can be viewed as an investment lost to the local economy, i.e., it may be viewed as a drain on financial resources locally. However, a potential advantage is the inflow of new entrepreneurial ideas, and possibly the inflow of entrepreneurs who are relocating. Indeed, some investors make it a funding requirement that the entrepreneurs relocate to the investor country.

From the perspective of the investee company's country, there are several issues at stake. As long as the company remains in its home country, the ecosystem effects are likely to be positive. However, 
the big concern is precisely that the company relocates to the investor country, possibly at the time of investment, possibly at a later stage, and possibly also at exit through a foreign acquisition. Things get even more complicated when we consider the dynamic flow of entrepreneurs who leave but sometimes come back at a later point in time. Section 3.2 elaborates on this further. An additional concern with foreign investors is that they may crowd out local investors. This could slow the growth of local VC markets and entrepreneurial ecosystems.

In this context, it is worth noting that foreign investors typically play different roles in VC deals than domestic investors. Broadly speaking, there are four relevant steps to the investment process: deal sourcing, deal structuring, deal managing, and exit. Domestic investors are particularly good at deal sourcing and deal structuring, as they are more familiar with the local competitive landscape. However, once companies are ready for the scale-up stage, domestic investors often lack the funds and expertise to grow these companies. This is where foreign investors specializing in scale-ups can play an important role. Foreign investors, especially from the US, tend to be larger, and therefore more able to contribute large funds at the scale-up stage. In addition to capital, foreign investors also provide connections to foreign markets and potential foreign acquirers (mostly US acquirers), which provide exit options that may be unavailable to smaller, localized investors.

\subsection{Flow of Talent across Borders}

One of the central concerns with cross-border investments is their effect on talent and company mobility. Do they encourage individual and/or companies to relocate? If so, when and how? There are four inflection points in the investment cycle where talent and companies might move, at (i) pre-investment; (ii) investment; (iii) exit; and (iv) post-exit.

Concerning the first point, brain drain comes at the very beginning and relates to the choices of individuals and their career aspirations, before a company is formed. Concerning the second point, company relocation occurs after the formation of the company. Brain drain and company relocation are central concerns to policy makers trying to build a local ecosystem. One practical challenge is that it is difficult to obtain reliable data. Entrepreneurial brain drain is hard to distinguish from broader patterns of migration, since it occurs prior to a company being formed. As for company relocation, the usual data sources, such as national registers, are highly deficient too, since they typically cannot capture what happens to the company once it leaves the national boundaries.

The third point about exit concerns the later periods of company development. This is often the most visible involvement of foreign countries. It makes the news when successful local companies get acquired by foreign entities-critical voices can often be heard. A recent case in point was the acquisition by Softbank of Arm, a successful UK company. ${ }^{5}$ The final point concerning brain regain is arguably the least obvious. This involves a host of activities that happen after a successful foreign exit. Founders may bring capital, talent, and networks back to their home country. The recycling of expertise from successful entrepreneurs who become angels and pass on their expertise to the next generation of entrepreneurs is also valuable (Hellmann and Thiele 2019). There is some empirical evidence that suggests that the emigration of talent can lead to brain regain (Batista et al. 2007; Beine et al. 2001).

How much relocation actually happens is largely a function of how strong the domestic ecosystem is. In a weak ecosystem, entrepreneurs are eager to leave, and have little reason to return. In a stronger ecosystem, there are fewer reasons to leave and more reasons to return. Moreover, entrepreneurs in stronger ecosystems have more power to negotiate with foreign investors and may find it easier to resist calls for relocation by foreign investors.

Another way of looking at the relocation challenge is through Startup Genome's ecosystem lifecycle model (Startup Genome 2017). As long as ecosystems are in the activation and early globalization phase, they lose talent and resources. However, once they pass to the globalisation phase they attract 
resources. Logically, the best set of policies are policies that accelerate the move to the globalization phase: inject global know-how, increase global connectedness and accelerate top start-ups. This is one of the key reasons why a coherent policy approach is not limited to attracting foreign investors, but also seeks to strengthen the domestic ecosystem at the same time.

According to the London-based investment firm Atomico, there are three phases of founder mobility. ${ }^{6}$ In the first phase, which is what policymakers often remember from the early 1990s, founders in Europe, Canada, or Israel moved to the US and were simply asked to relocate (primarily to Silicon Valley) by their foreign investors. In the second phase, founders no longer need to relocate to the US; rather, they consider moving to a larger local hub in Europe, mainly London. In the third phase, the strengths of regional hubs in Europe increasingly allow start-up founders to stay in their home region, often in larger country hubs such as Berlin or Paris, but occasionally even in smaller towns. According to Atomico, Europe is currently somewhere between the second and third phase.

\section{Policy Options}

Given the varied country experiences, there cannot be a prescriptive, one-size-fits all policy that perfectly balances domestic versus foreign VC investments. However, in this section we consider how policymakers can think systematically about the role of cross-border VC investments.

\subsection{Rationale for Public Support of Cross-Border VC}

There is a set of core arguments about the rationale for government support of venture capital. VC investments support innovation, employment, and productivity growth (Brander et al. 2015; Lerner 2010). Many factors lead to market imperfections and failures when it comes to financing entrepreneurial ventures. Start-ups are particularly difficult to assess given their short history and intangible assets. This makes assessing a small company's need for funds and the potential financial returns difficult and costly (Kraemer-Eis and Lang 2012). Asymmetries of information surrounding start-ups thus generate a level of uncertainty for investors that can lead to suboptimal funding levels. A large economic literature examines problems of agency theory and credit rationing (Akerlof 1970; Arrow 1985; Jaffee and Russell 1976; Stiglitz and Weiss 1981). All of those can be used to justify public intervention. However, their benefits always have to be weighed against the costs of government intervention, especially the risks of government failures. In the European context, additional complicating factors are the fragmented national borders, disparate legal systems, cultural disparity regarding risk taking, and the risk of double taxation (Wilson 2015; Tykvová et al. 2012).

These core rationales for government support of VC investments need to be extended in our context, to consider the unique challenges posed by cross-border VC investing. The question is not merely whether government want to support venture capital, but whether they want to support foreign venture capital. There are several debates that feed into this.

First, there is the question of whether government should encourage or discourage foreign ownership. In practice, government-sponsored VC funds, such as the British Business Bank in the UK, Bpifrance or the Business Development Bank of Canada, are bound by their mandates, and are under constant political scrutiny, being monitored on where they allocate public funds. These mandates sometime directly or indirectly limit investment in foreign funds or foreign companies by funds or funds of funds that receive public funds directly or indirectly. This is a challenge for foreign investors looking to co-invest in companies receiving public funds. It may also limit the choices of domestic companies receiving public funds.

There are several other issues that make foreign ownership politically problematic. It is clearly difficult for governments to control foreign investors, not to mention their governments. Foreign

6 This section is based on conversations with Atomico. Atomico is a leading international technology investment firm headquartered in London. Atomico's founder and CEO is Niklas Zennström, who co-founded Skype and Kazaa. 
entities may decide to take decisions that undermine the domestic economy without bearing much of the consequences. There is also the possibility that foreign investors are subjected to their own domestic regulations, which then impact their company investments abroad. Finally, there is the recent rise of economic nationalism that poses a challenge for foreign investments. Beyond a rational evaluation of the advantages and disadvantages of foreign ownership, there is often recourse to a simplistic argument that foreign ownership is undesirable by itself.

Overall, we note that even though there are some solid reasons for governments to support venture capital investments, including from foreign investors, in practice there are also ways that governments can implicitly limit these investments. As a consequence, it is important to map out the broad policy options available for policymakers to consider. In the next subsection, we identify ten key policy options that address ways to build a strong domestic base and attract foreign investors at the same time. In principle, these policy options are available to most policymakers, although there is no strong consensus yet on which policies are most effective, nor under what circumstances they are more or less effective.

\subsection{Policy Options}

Table 4 provides an overview of what we consider the ten most important policy options relevant in practice. It uses the two levels of analysis from the framework in Figure 2, namely the transaction and ecosystem level. In addition, it distinguishes between two policy goals: strengthening the domestic VC market and attracting foreign investors. Note that the boundaries within this framework are not strict. Some policies may have effects both at the transaction and ecosystem level, or they may help to strengthen the domestic base as well as attract foreign investors.

Table 4. Comparison of public policies towards cross-border investments.

\begin{tabular}{|c|c|c|c|}
\hline Level & Objective & $\#$ & Policy Option \\
\hline \multirow{2}{*}{ Transaction level } & Building domestic base & $\begin{array}{l}1 \\
2\end{array}$ & $\begin{array}{l}\text { Tax credits } \\
\text { Funding programmes }\end{array}$ \\
\hline & $\begin{array}{l}\text { Attracting foreign } \\
\text { investors }\end{array}$ & $\begin{array}{l}3 \\
4\end{array}$ & $\begin{array}{l}\text { Open up tax credits } \\
\text { Open up funding } \\
\text { programmes }\end{array}$ \\
\hline \multirow[t]{2}{*}{ Ecosystem level } & Building domestic base & $\begin{array}{l}5 \\
6 \\
7\end{array}$ & $\begin{array}{l}\text { Sectoral focus } \\
\text { Attracting talent } \\
\text { Human capital } \\
\text { development }\end{array}$ \\
\hline & $\begin{array}{l}\text { Attracting foreign } \\
\text { investors }\end{array}$ & $\begin{array}{l}8 \\
9 \\
10\end{array}$ & $\begin{array}{l}\text { Harmonization } \\
\text { Networking } \\
\text { Transparency }\end{array}$ \\
\hline
\end{tabular}

Policy option \#1 looks at tax credits, which are transaction-level policies meant to strengthen domestic companies. There are many different types of tax credits, including company tax credits (such as for R\&D), investment tax credits (typically a percentage of qualifying investment amounts), or capital gains relief (OECD Publishing 2018). There is a heathy debate about the desirability and effectiveness of such tax credit policies, but there is an emerging consensus that a reasonable level of tax support helps to foster local innovation ecosystems.

Policy option \#2 concerns VC funding policies, which are another example of policies for strengthening the domestic ecosystem. They include a variety of government initiatives that motivate private investors to create VC funds to support local companies, from young start-ups to more mature scale-up companies. Examples include the European Investment Fund's venture capital programmes, (parts of) the European Commission's Capital Markets Union Action Plan, programmes funded by British Business Banks and Bpifrance or the Venture Capital Action Plan (VCAP) and the Venture 
Capital Catalyst initiative (VCCI) in Canada. Their effectiveness also remains a matter of debate, but in Europe there is a broad consensus that a reasonable implementation of such government programmes helped to stabilize and grow the European VC industry (Brander et al. 2015; Brander et al. 2010; Lerner 2010; Prencipe 2017; Signore and Torfs 2017).

While policies \#1 and \#2 are meant to help the domestic ecosystem to develop, on their own they do not attract foreign investors. This is because the usual design of these programmes focused on domestic investors. Opening them up to foreign investors has the potential of increasing their economic impact. Yet doing so is far from trivial in practice. Let us understand the main challenges.

Consider policy option \#3, which foresees opening up investment tax credits to foreign investments. The economic logic is simple: if there are economic benefits to incentivizing certain investments, then this should be true irrespective of the location of the investor. In practice, however, this is politically sensitive. Domestic tax credits are not universally popular within their domestic context, and there is a general reluctance to offer foreign investors the same subsidies as domestic investors. Another important limitation is that foreign investors typically do not have tax liabilities to offset. This can be an issue with investment credits (such as the UK's EIS/SEIS system) but would not be an issue with capital gains tax credits. It can also be addressed by making tax credits directly refundable-this approach is currently used in places such as British Columbia or Minnesota.

Policy option \#4 asks for domestic programmes (discussed under policy option \#2) to also be accessible to foreign investors. In the case of funding programmes, this means allowing foreign GPs to gain access to the funding offered by the government as an LP. If all the foreign GPs were to do was take the money and invest it elsewhere, then this would clearly not generate any domestic economic benefits (although it might still generate good financial returns). The government's intent is clearly that the GPs (domestic or foreign) invest the majority of the money in the domestic economy. This suggests using rules about the minimum amount of domestic (or equivalently maximum amount foreign) investment allowable in a fund. Currently, some government programmes have introduced such rules. The British Business Bank, for example, requires all of the funds to invest at least twice as much in the UK as its share of the fund (which is well below $50 \%$ of the total fund, thus making this rule feasible). Similar rules also apply to Canada, such as the investments under the VCAP and VCCI programme, as well as the BDC.

The four policy options considered so far all address financial incentives at the transactional level. The remainder of the policy options operate at the ecosystems level. Policies \#5-\#10 are non-financial in nature but affect the connections that local entrepreneurs and investors have access to within their own ecosystem, as well as how they connect to foreign investors.

Policy option \#5 looks at sector specialization. Governments have some leeway on which technologies and sectors to favour depending on the countries' industrial policies. To begin with, government play an important role in promoting basic science and applied R\&D (Klette et al. 1999). Policy makers have their own preferences about what sectors should be favoured and what policies can be used for that purpose (Vuong 2018). Related to this, governments promote centres of excellence in a variety of ways. The economic rationale can often be to focus innovation efforts on a few select areas where the ecosystem has a chance to compete on a global basis. The Canadian Innovation Superclusters Initiative is an example of this type of initiative. ${ }^{7}$ The benefit with respect to foreign VC investments is that a company (or country) has a stronger bargaining position when part of a local centre of excellence. The likelihood of being asked to relocate the company is considerably lower, since the local ecosystem is already world class. More generally, the negotiating dynamics are entirely different if companies in

7 Innovation clusters are a dense area of business activity containing a critical mass of large and small companies, post-secondary and other research institutions that act as engines of growth. Superclusters build on the advantages of a cluster via stronger connections, a long-term competitive advantage, and global brand recognition. The Innovation Superclusters Initiative in Canada is investing up to $\$ 950$ million to support business-led innovation superclusters with the greatest potential to energize the economy and become engines of growth (https://www.ic.gc.ca/eic/site/093.nsf/eng/home). 
the ecosystem are able to attract competitive bids from multiple foreign investors, as opposed to being at the mercy of a single foreign investor. The key insight for policy option \#5 is that a country or region may be in a weak bargaining position in one, but in a strong bargaining position in another sector, depending on where its comparative advantages lie.

Policy option \#6 focuses on labour market policies, especially immigration laws, as well as efforts to reconnect with successful expat entrepreneurs. Policymakers often emphasize the negative by-products of foreign investments on the ecosystem, in terms of brain drain. However, merely bemoaning the loss of talent is hardly useful. Most legal approaches of preventing brain drain are both ineffective and ethically questionable. The challenge is therefore to devise policies that attract (and possible regain) talent. One of the reasons of Silicon Valley's success is the influx of immigrants (Saxenian 2002). In the US, 56\% of the most highly valued technology companies, along with 1.7 million employees, were founded by first- or second-generation Americans (Meeker 2018). Policy initiatives aimed to attract immigrant entrepreneurs (e.g., the White House Startup America initiative and Start-up Visa Programme in Canada) can strengthen the domestic entrepreneurial environment.

From a European perspective, there is an ongoing challenge of reforming labour market and increasing labour mobility within Europe. Another less studied question is how to reconnect with successful entrepreneurs and venture capitalists that left for other countries, such as the US. The most important fact here is the virtual absence of any organized efforts to do this. By contrast, in Canada, the C-100 is widely considered a useful (albeit arguably still insufficient) effort to reconnect successful Canadian entrepreneurs in Silicon Valley with the Canadian innovation ecosystem. ${ }^{8}$ The conjecture is that relatively simple initiatives by governments and private actors could help to reinvigorate the interest of successful entrepreneurs and venture capitalists to reconnect with the countries they originally came from.

Ecosystem-level policies can strengthen the entrepreneurial human capital in the ecosystem, as well as create a supportive environment to retain top entrepreneurial talent. Policy option \#7 looks at policies for investing in enterprise training and education at various levels (Duruflé 2018). For example, the Invest Europe's "Foundation for Venture Capital Investment Professionals" is a training programme designed for early-career practitioners to learn about the different milestones and processes in private equity investment. Universities and technical colleges also play a large role in educating potential entrepreneurs and supporting emerging student entrepreneurs (Duruflé 2018; Papayannakis et al. 2008; Wilson and Silva 2013; Twaalfhoven and Wilson 2004; Wilson et al. 2009).

Ecosystem-level policies to strengthen the domestic base can target domestic companies, as well as individuals. Some initiatives that strengthen the start-up ecosystem include the European Commission's Innovation Radar Platform, which is a database of ventures designed to help broker contact between EU-funded innovators and investors who can help them commercialize their innovation via expertise or capital, or simply engage in knowledge exchange.

Policy option \#8 is specifically focused on the European context and identifies the ever-present challenge of regulatory harmonization (Goodhart and Schoenmaker 2016). Clearly, this topic has been addressed within the European Union for decades. In the financial arena, it received an important boost with the Capital Markets Union initiative ${ }^{9}$ However, many regulatory harmonization issues continue to impede foreign investments. One novel idea concerns the rules of incorporation, the notion of developing some kind of equivalent to the Delaware C-Corp for Europe. However, any such initiative would require extensive cooperation among European Union members and would likely take a long time to be developed. In the meantime, there are many other areas of harmonization identified by the Capital Markets Union initiative that would also help to create a level playing field for investing across Europe. Canada, for example, benefited from a boost of US investments after getting rid of legal

8 See https://www.thec100.org/.

9 See https://ec.europa.eu/info/business-economy-euro/growth-and-investment/capital-markets-union_en. 
barriers (especially Section 116 of the Income Tax Act) that had made US venture investment in Canada cumbersome and costly.

Policy option \#9 concerns international networks, which involves both hard and soft policies. In terms of hard policies, specific funding initiatives can link the domestic companies with foreign investors and expertise. Backed by $€ 410$ million of EU funding, the European Investment Fund and the European Commission launched in 2018 a Pan-European Venture Capital Funds-of-Funds programme (VentureEU) to boost investment in innovative start-up and scale-up companies across Europe. ${ }^{10}$ This is in addition to the Pan-European Venture Capital Fund-of-Funds programme, which was launched in 2016 to tackle Europe's equity gap, the fragmentation of the VC market, and to attract additional private funding from institutional investors into the EU venture capital asset class. ${ }^{11}$

In addition, there are numerous soft policies that strengthen global networks. Governments often have direct and indirect powers to convene diverse ecosystem actors. Current examples of international initiatives focused on innovation and ecosystem building include Startup Genome, Endeavor Insight, the Tech Innovation Platform (TIP) and the Global Entrepreneurship Research Network (GERN). Global networking initiatives and international trade missions with a sector focus, such as the European Blockchain Partnership and AI Summit, may also help to promote cross-border investments. Finally, international conferences play a role in building global connectedness, including the Kauffman Fellows Annual Summit and the Web Summit.

The last policy option \#10 about transparency may be the simplest of all, yet also the least intuitive to many industry participants. Transparency does not come natural to the venture capital industry, which is traditionally opaque with regards to its portfolio performance. This model is currently challenged by the crowdfunding model, which is inherently much more transparent. However, the venture capital model continues to lack in transparency to outsiders. While this fits the competitive instincts of the incumbents, it also limits entry into the industry, including entry by foreign investors. There is a long-standing problem in the industry around the measurement and disclosure of investment returns, as there are few legal requirements for general or limited partners to disclose their returns. As a consequence, returns date remains unreliable, out-dated, and often biased. Yet governments and industry associations could easily take initiatives to increase the transparency of the industry (Nougayrède 2018), better utilizing existing information channels, and/or devising novel ways of collecting industry data. This by itself would be a long-term investment with limited benefits in the short run, but it would help to build the credibility of an ecosystem, and over time generate trust with foreign investors.

\section{Discussion}

Cross-European investments, as well as US and Asian investments in Europe and abroad, are becoming more common. Nevertheless, policies regarding cross-border financing vary widely. To date, rhetoric has remained predominantly binary, where policymakers are either "for" or "against" policies that attract foreign VC investment. Moreover, many policy makers are simply not aware how their policies might implicitly encourage or discourage foreign investment. The goal of this paper is to introduce a nuanced approach for policymakers to make a more robust and dynamic evaluation of the role of government in cross-border VC investments. Our core framework identifies two broad types of policies: "transaction-level" policies that focus on facilitating foreign investments, and "ecosystem-level" policies that foster the development of the local entrepreneurial ecosystem. The most important insight from our work is that these two types of policies interact with each other and should be addressed in tandem. They should also be adjusted over time as the market develops. A country that works to strengthen its domestic base through ecosystem-level policies can

10 See http://www.eif.org/what_we_do/equity/news/2018/paneuropean-VC-FoF.htm.

11 See http://www.eif.org/what_we_do/equity/paneuropean_venture_capital_fund_of_funds/index.htm. 
mitigate the adverse effects that sometimes follow transaction-level policies attracting foreign investors. Alternatively, a country already endowed with a strong domestic base can simultaneously create transaction-level policies to attract foreign investors. Our core message to policymakers is, therefore, that they should work concurrently on transaction-level and ecosystem-level policies. By doing so, policies to strengthen a country's domestic base, as well as attract foreign investors, can work together to grow a healthy and sustainable VC ecosystem.

Author Contributions: Conceptualization, W.A.B., G.D., T.F.H. and K.E.W.; Methodology, W.A.B., G.D., T.F.H. and K.E.W.; Validation, W.A.B., G.D., T.F.H., and K.E.W.; Formal Analysis, W.A.B., G.D., T.F.H. and K.E.W.; Investigation, W.A.B., G.D., T.F.H. and K.E.W.; Resources, W.A.B., G.D., T.F.H. and K.E.W.; Data Curation, W.A.B., G.D., T.F.H. and K.E.W.; Writing - Original Draft Preparation, W.A.B., G.D., T.F.H. and K.E.W.; Writing-Review \& Editing, W.A.B., G.D., T.F.H. and K.E.W.; Visualization, W.A.B., G.D., T.F.H. and K.E.W.; Supervision, W.A.B., G.D., T.F.H. and K.E.W.; Project Administration, W.A.B., G.D., T.F.H. and K.E.W.; Funding Acquisition, W.A.B., G.D., T.F.H. and K.E.W.

Funding: This research received no external funding.

Acknowledgments: We would like to thank the participants of the Oxford Entrepreneurship Policy Roundtable on 18 May 2018, for their many useful insights. We gratefully acknowledge the financial support from the Goldman Sachs 10,000 Small Businesses Programme. The views expressed in this paper are solely those of the authors.

Conflicts of Interest: The authors declare no conflict of interest. The funders had no role in the design of the study; in the collection, analyses, or interpretation of data; in the writing of the manuscript; or in the decision to publish the results.

\section{References}

Acevedo, Miguel F., Matt Adey, Claudio Bruno, Gino del Bufalo, Alexandre Gazaniol, Vivien Lo, Georg Metzger, Blanca N. Perez, and Baptiste Thornary. 2016. Building Momentum in Venture Capital across Europe: France, Germany, Italy, Spain and the United Kingdom. Maisons-Alfort: Bpifrance, Rome: Cassa depositi e prestiti, Madrid: Instituto de Credito Oficial, Sheffield: British Business Bank, Frankfurt am Main: KfW Bankengruppe, Available online: https://www.kfw.de/PDF/Download-Center/Konzernthemen/Research/PDF-DokumenteStudien-und-Materialien/Building-Momentum-in-Venture-Capital-across-Europe.pdf (accessed on 1 June 2018).

Aizenman, Joshua, and Jake Kendall. 2008. The Internationalization of Venture Capital and Private Equity. Cambridge: National Bureau of Economic Research. [CrossRef]

Akerlof, George A. 1970. The Market for "Lemons": Quality Uncertainty and the Market Mechanism. The Quarterly Journal of Economics 84: 488. [CrossRef]

Alhorr, Hadi S., Curt B. Moore, and G. Tyge Payne. 2008. The Impact of Economic Integration on Cross-Border Venture Capital Investments: Evidence from the European Union. Entrepreneurship Theory and Practice 32: 897-917. [CrossRef]

Arrow, Kenneth J. 1985. The economics of agency. In Principals and Agents: The Structure of Business. Edited by J. W. Pratt and R. Zeckhauser. Boston: Harvard Business School Press.

Autorité des Marchés Financiers. 2014. BPI France, Annual Report. Paris: Autorité des Marchés Financiers.

Batista, Catia, Aitor Lacuesta, and Pedro C. Vicente. 2007. Brain Drain or Brain Gain? Micro Evidence from an African Success Story. Bonn: IZA.

Beine, Michel, Frédéric Docquier, and Hillel Rapoport. 2001. Brain drain and economic growth: Theory and evidence. Journal of Development Economics 64: 275-89. [CrossRef]

Bertoni, Faio, and Alexander Peter Groh. 2014. Cross-Border Investments and Venture Capital Exits in Europe: Mode of Exit and Cross-Border VC Investments. Corporate Governance: An International Review 22: 84-99. [CrossRef]

Bordo, Matan. 2018. Israeli Tech's Identity Crisis: Startup Nation or Scale Up Nation? Available online: https://www.forbes.com/sites/startupnationcentral/2018/05/14/israeli-techs-identity-crisis-startupnation-or-scale-up-nation/ (accessed on 14 May 2018).

Bottazzi, Laura, Marco Da Rin, and Thomas Hellmann. 2009. What is the role of legal systems in financial intermediation? Theory and evidence. Journal of Financial Intermediation 18: 559-98. [CrossRef] 
Bottazzi, Laura, Marco Da Rin, and Thomas Hellmann. 2016. The Importance of Trust for Investment: Evidence from Venture Capital. Review of Financial Studies 29: 2283-318. [CrossRef]

Brander, James A., Qianqian Du, and Thomas Hellmann. 2015. The Effects of Government-Sponsored Venture Capital: International Evidence. Review of Finance 19: 571-618. [CrossRef]

Brander, Luke M., Andrea Ghermandi, Onno Kuik, Anil Markandya, Paulo A. L. D. Nunes, Marije Schaafsma, and Alfred Wagtendonk. 2010. Scaling Up Ecosystem Services Values: Methodology, Applicability and a Case Study. SSRN Electronic Journal. [CrossRef]

BDC Capital. 2017. BDC Capital Canada's Venture Capital Landscape: Challenges and Opportunities. Wakefield: BDC Capital Database.

Chahine, Salim, and Samer Saade. 2011. Shareholders' Rights and the Effect of the Origin of Venture Capital Firms on the Underpricing of US IPOs: Shareholders' Rights and the Origin of Venture Capital Firms. Corporate Governance: An International Review 19: 601-21. [CrossRef]

Chemmanur, Thomas J., Tyler J. Hull, and Karthik Krishnan. 2016. Do local and international venture capitalists play well together? The complementarity of local and international venture capitalists. Journal of Business Venturing 31: 573-94. [CrossRef]

Chen, Victor Zitian, and Sunny Li Sun. 2019. Barbarians at the gate of the middle kingdom: The international mobility of financial contracting and governance. Entrepreneurship Theory and Practice 43: 802-37. [CrossRef]

Dealroom.co. 2017. Annual European Venture Capital Report, European ed. Amsterdam: Dealroom.co Database.

Dealroom.co. 2018. Capital Investment Flows in Europe. Amsterdam: Dealroom.co Database.

Devigne, David, Tom Vanacker, Sophie Manigart, and Ine Paeleman. 2013. The role of domestic and cross-border venture capital investors in the growth of portfolio companies. Small Business Economics 40: 553-73. [CrossRef]

Devigne, David, Sophie Manigart, and Mike Wright. 2016. Escalation of commitment in venture capital decision making: Differentiating between domestic and international investors. Journal of Business Venturing 31: 253-71. [CrossRef]

Devigne, David, Sophie Manigart, Tom Vanacker, and Klaas Mulier. 2018. Venture capital internationalization: Synthesis and future research directions. Journal of Economic Surveys 32: 1414-45. [CrossRef]

Duruflé, Gilles. 2018. 2018 Main Conclusions. Presented at the Tech Innovation Platform, Quebec City Conference, Quebec City, QC, Canada; Available online: https://qcconference.com/archives/tip/ (accessed on 15 November 2018).

Duruflé, Gilles, Thomas Hellmann, and Karen Wilson. 2018. Catalysing entrepreneurship in and around universities. Oxford Review of Economic Policy 34: 615-36. [CrossRef]

Gilder, G. 2009. Silicon Israel: How Market Capitalism Saved the Jewish State. City Journal 19. Available online: https://www.city-journal.org/html/silicon-israel-13208.html (accessed on 1 June 2018).

Goodhart, Charles, and Dirk Schoenmaker. 2016. The Global Investment Banks are now all Becoming American: Does that Matter for Europeans? Journal of Financial Regulation 2: 163-81. [CrossRef]

Groh, Alexander P., and Heinrich Liechtenstein. 2011. International allocation determinants for institutional investments in venture capital and private equity limited partnerships. International Journal of Banking, Accounting and Finance 3: 176-206. [CrossRef]

Groh, Alexander P., Heinrich Liechtenstein, and Miguel A. Canela. 2008. International Allocation Determinants of Institutional Investments in Venture Capital and Private Equity Limited Partnerships. IESE Research Papers D/726. Barcelona: IESE Business School. [CrossRef]

$\mathrm{Gu}$, Qian, and Jane W. Lu. 2010. Effects of inward investment on outward investment: The venture capital industry worldwide 1985-2007. Journal of International Business Studies 42: 263-84. [CrossRef]

Guler, Isin, and Mauro F. Guillén. 2010. Institutions and the internationalization of US venture capital firms. Journal of International Business Studies 41: 185-205. [CrossRef]

Hellmann, Thomas, Denis Frydrych, Carolyn Hicks, Christian Rauch, Francisco Brahm, Christoph Loch, Stelios Kavadias, and Peter Hiscocks. 2016. Financing UK Scale-Ups: Challenges and Recommendations. Available online: http://eureka.sbs.ox.ac.uk/id/eprint/6148 (accessed on 1 June 2018).

Hellmann, Thomas F., and Veikko Thiele. 2019. Fostering Entrepreneurship: Promoting Founding or Funding? Management Science 65: 2445-2945. [CrossRef]

Huang, Eustance. 2018. Chinese Investment in Israeli TECH Is Growing, and It's "Quite Welcome” for Some. CNBC. Available online: https:/www.cnbc.com/2018/07/19/chinese-investment-in-israel-technology-is-growingexpert-says.html (accessed on 1 June 2018). 
Humphery-Jenner, Mark, and Jo-Ann Suchard. 2013. Foreign VCs and venture success: Evidence from China. Journal of Corporate Finance 21: 16-35. [CrossRef]

Hursti, Jani, and Markku V. J. Maula. 2008. Acquiring Financial Resources from Foreign Equity Capital Markets: An Examination of Factors Influencing Foreign Initial Public Offerings. Journal of Business Venturing 22: 833-51. [CrossRef]

Isenberg, Daniel. 2011. Start-up Notions: Where Israeli Entrepreneurship Really Came From. Jersey City: Forbes.

Jääskeläinen, Mikko, and Maula Maula. 2014. Do networks of financial intermediaries help reduce local bias? Evidence from cross-border venture capital exits. Journal of Business Venturing 29: 704-21. [CrossRef]

Jaffee, Dwight M., and Thomas Russell. 1976. Imperfect Information, Uncertainty, and Credit Rationing. The Quarterly Journal of Economics 90: 651. [CrossRef]

Klette, Tor, Jarle Møen, and Zvi Griliches. 1999. Do Subsidies to Commercial RED Reduce Market Failures? Microeconometric Evaluation Studies. NBER Working Paper, (w6947). Cambridge: National Bureau of Economic Research, Inc., p. 37.

Kraemer-Eis, Helmut, and Frank Lang. 2012. The Importance of Leasing for SME Financing. Working Paper. p. 36. Available online: http://www.eif.org/news_centre/research/eif_wp_2012_15_The\%20importance \% 20of\%20leasing\%20for\%20SME\%20finance_August_2102.pdf (accessed on 1 June 2018).

Lee, Georgina. 2018. Canada's Tech Firms Drawing Increasing Interest from Chinese Venture Capital Firms. South China Morning Post. Available online: https://www.scmp.com/business/article/2130409/canadas-tech-firmsdrawing-increasing-interest-chinese-venture-capital (accessed on 25 January 2018).

Lerner, Josh. 2010. The future of public efforts to boost entrepreneurship and venture capital. Review of Finance 571. [CrossRef]

Mäkelä, Markus M., and Markku V. J. Maula. 2005. Cross-border venture capital and new venture internationalization: An isomorphism perspective. Venture Capital 7: 227-57. [CrossRef]

Mäkelä, Markus M., and Markku V. J. Maula. 2006. Interorganizational Commitment in Syndicated Cross-Border Venture Capital Investments. Entrepreneurship Theory and Practice 30: 273-98. [CrossRef]

Mäkelä, Markus M., and Markuu V. J. Maula. 2008. Attracting cross-border venture capital: the role of a local investor. Entrepreneurship \& Regional Development 20: 237-57. [CrossRef]

Meeker, Mary. 2018. Internet Trends. Menlo Park: Kleiner, Perkins, Caufield \& Byers Partner.

Meuleman, Miguel, and M. Wright. 2009. Determinants of Cross-Border Syndication: Cultural Barriers, Legal Context, and Learning. Available online: https://ssrn.com/abstract=1348206 (accessed on 1 June 2018).

Nougayrède, Delphine. 2018. Towards a Global Financial Register? The Case for End Investor Transparency in Central Securities Depositories. Journal of Financial Regulation 4: 276-313. [CrossRef]

OECD Publishing. 2018. OECD Time-Series Estimates of Government Tax Relief for Business RED: Technology and Industry Policy Papers. Paris: OECD Publishing, Available online: https://www.oecd.org/sti/rd-tax-stats-taxexpenditures.pdf (accessed on 1 June 2018).

Papayannakis, L., I. Kastelli, D. Damigos, and G. Mavrotas. 2008. Fostering entrepreneurship education in engineering curricula in Greece. Experience and challenges for a Technical University. European Journal of Engineering Education 33: 199-210. [CrossRef]

Pierrakis, Y., and G. Saridakis. 2019. The role of venture capitalists in the regional innovation ecosystem: A comparison of networking patterns between private and publicly backed venture capital funds. The Journal of Technology Transfer 44: 850-73. [CrossRef]

PitchBook. 2015. Canada Breakdown Report. Seattle: PitchBook.

PitchBook. 2017. Canadian PE \& VC Breakdown Report. Seattle: PitchBook.

Prencipe, Dario. 2017. The European Venture Capital Landscape: An EIF Perspective. Volume III: Liquidity Events and Returns of EIF-Backed VC Investments. Luxembourg: European Investment Fund.

PwC/CB Insights Canada. 2018. MoneyTree Canada Report (PwC/CB Insights Quarterly Report, Q4,2017). Toronto: PwC/CB Insights.

Razin, Assaf. 2018. High Tech and Venture Capital Inflows: The Case of Israel. Cambridge: National Bureau of Economic Research. [CrossRef]

Saxenian, Anna Lee. 2002. Silicon Valley's New Immigrant High-Growth Entrepreneurs. Economic Development Quarterly 16: 20-31. [CrossRef] 
Signore, Simone, and Wouter Torfs. 2017. The European Venture Capital Landscape: An EIF Perspective. Volume IV: The Value of Innovation for EIF-Backed Startups. EIF Working Paper Series. Available online: https://EconPapers.repec.org/RePEc:zbw:eifwps:201745 (accessed on 1 June 2018).

Sorenson, Olav, and Toby E. Stuart. 2001. Syndication Networks and the Spatial Distribution of Venture Capital Investments. American Journal of Sociology 106: 1546-88. [CrossRef]

Startup Genome. 2017. Global Startup Ecosystem Report. San Francisco: Startup Genome.

Stiglitz, Joseph, and Andrew Weiss. 1981. Credit Rationing in Markets with Imperfect Information. American Economic Review 71: 393-410.

Sun, S. L., V. Z. Chen, S. Sunny, and J. Chen. 2018. Venture capital as an ecosystem engineer for regional innovation co-evolution in an emerging market. International Business Review. forthcoming. [CrossRef]

Sun, Sunny Li, and Hao Liang. 2014. Morphing: The linkage of inward private equity and outward venture. Thunderbird International Business Review 56: 421-38. [CrossRef]

The Economist. 2017. Startup nation or left-behind nation? Israel's economy is a study in contrasts. The Economist, May 18.

Twaalfhoven, Bert, and Karen E. Wilson. 2004. Breeding More Gazelles: The Role of European Universities. Available online: http://www.gvpartners.com/web/pdf/Breeding_Gazelles_-_The_Role_of_Universities.pdf (accessed on 1 June 2018).

Tykvová, Tereza, Mariela Borell, and Tim-Alexander Kroencke. 2012. Potential of Venture Capital in the European Union. Brussels: European Parliament.

Tykvová, Tereza, and Andrea Schertler. 2008. Syndication to Overcome Transaction Costs of CROSS-border Investments? Evidence from a Worldwide Private Equity Deals' Dataset. Working Paper. Available online: https:/pdfs.semanticscholar.org/85ab/01f03d2614330b485ad951de6379a5ba88be.pdf?_ga=2. 105797699.155263369.1561955345-1609756567.1536308798 (accessed on 1 June 2018).

Tykvová, Tereza, and Andrea Schertler. 2011. Cross-border venture capital flows and local ties: Evidence from developed countries. The Quarterly Review of Economics and Finance 51: 36-48. [CrossRef]

Vuong, Quan-Hoang. 2018. The (ir)rational consideration of the cost of science in transition economies. Nature Human Behaviour 2: 5. [CrossRef]

Weinland, Don. 2018. Chinese VC Funds Pour \$2.4bn into Silicon Valley Start-Ups. Financial Times. Available online: https://www.scmp.com/business/article/2130409/canadas-tech-firms-drawing-increasing-interestchinese-venture-capital (accessed on 18 July 2018).

Wilson, Karen, and Filipe Silva. 2013. Policies for Seed and Early Stage Finance: Findings from the 2012 OECD Financing Questionnaire. OECD Science, Technology and Industry Policy Papers. Paris: OECD Publishing. [CrossRef]

Wilson, Karen E., Shai Vyakarnam, Christine Volkmann, Steve Mariotti, and Daniel Rabuzzi. 2009. Educating the Next Wave of Entrepreneurs: Unlocking Entrepreneurial Capabilities to Meet the Global Challenges of the 21st Century. SSRN Electronic Journal. [CrossRef]

Wilson, Karen E. 2015. Policy Lessons from Financing Innovative Firms. OECD Science, Technology and Industry Policy Papers 24. Paris: OECD Publishing. [CrossRef]

Zemer, Manor. 2018. Funding for Israeli High-Tech Hits All-Time High. Available online: http://www.israel-vc. com/2016/02/2015-funding-for-israeli-high-tech-hits.html (accessed on 15 November 2018).

(C) 2019 by the authors. Licensee MDPI, Basel, Switzerland. This article is an open access article distributed under the terms and conditions of the Creative Commons Attribution (CC BY) license (http://creativecommons.org/licenses/by/4.0/). 